Disclosure of Interests: None declared

DOI: 10.1136/annrheumdis-2019-eular.4039

\section{OP0049 1 FACTORS ASSOCIATED WITH EARLY FLARES WHEN INITIATING URATE LOWERING THERAPIES. POST HOC ANALYSIS OF CLEAR 1,2 AND CRYSTAL TRIALS}

Pascal Richette ${ }^{1}$, Fernando Perez-Ruiz ${ }^{2}$, Ravi Karra ${ }^{3}$, Augustin Latourte', Imane Wild ${ }^{3}$, Prashanth Kandaswamy ${ }^{3}$, Heiko Hagedorn ${ }^{3}$, Thomas Bardin ${ }^{1}$. ${ }^{1}$ Hopital Lariboisière, Paris, France; ${ }^{2}$ Senvicio de Reumatología, Hospital Universitario Cruces, Cruces, Spain; ${ }^{3}$ Grunenthal, Aachen, Germany

Background: Initiation of urate lowering therapies (ULT) in patients with gout can trigger flares which could contribute to poor treatment adherence. The EULAR guidelines recommend a prophylactic treatment with colchicine or low dose NSAIDs for up to 6 months. However, long term treatment with either NSAIDs or colchicine can be poorly tolerated or contra-indicated. Thus, identification of risk factors for flares to identify patients who would benefit more from a prophylactic treatment could improve patients care.

Objectives: To investigate the influence of patient and treatment related factors on the occurrence of flares 1 month after the initiation of ULT.

Methods: Data are from $n=1018$ patients (mean age 52.0 (SD 11.1) years; $95.2 \%$ male) not responding to allopurinol or febuxostat monotherapy and who received lesinurad (200 mg or $400 \mathrm{mg}$ ) in the CLEAR and CRYSTAL trials. Patients were prescribed colchicine $(84 \%)$ or NSAIDs $(12.9 \%)$ as prophylactic treatment. Data from 3 trials were pooled and the following covariates were considered in the main analysis using a Generalized Estimation Equation (GEE) model: age, gender, serum uric acid (SUA) levels, baseline body mass index, renal function, and presence of tophus, type of gout flare prophylaxis, triglycerides, comorbidities (smoking, tobacco, diabetes, hypertension, hyperlipidemia) antihypertensive and lipid lowering medications at baseline and newly started and change in SUA levels. A multivariate analysis was conducted using the occurrence of flares as response measured from baseline until month 1

Results: In the multivariate analysis, tophus at baseline and gender (female) were both associated with an increased risk of early flares: OR=2.7 (95\% Cl: $1.7-$ 4.2) and $\mathrm{OR}=1.8$ (95\%: $\mathrm{Cl}$ 1.0-3.4), respectively, whereas hyperlipidemia and hypertension were associated with a decreased risk of flares: OR=0.64 (95\%: $\mathrm{Cl}$ $0.45-0.91)$ and $\mathrm{OR}=0.62$ (95\%: $\mathrm{Cl} 0.39-0.99)$. There was a trend toward a reduced risk of flares with colchicine versus NSAIDs: OR=0.71 (95\%: Cl 0.471.05). Neither the duration of gout nor the change in SUA levels modified the risk of flares.

Conclusion: This analysis shows that gender (female) and tophus are independent risk factors of early flares when initiating ULT, and suggests that colchicine might be more effective than low dose NSAIDs as prophylactic treatment.

Disclosure of Interests: Pascal Richette Consultant for: Grunenthal, Horizon, Speakers bureau: AstraZeneca, Grunenthal, Fernando Perez-Ruiz Grant/ research support from: Cruces Rheumatology Association, Consultant for: Grunenthal, Menarini, Horizon, Speakers bureau: Menarini, Grunenthal; Spanish foundation for rheumatology, Ravi Karra Employee of: Grunenthal, Augustin Latourte: None declared, Imane Wild Employee of: Grunenthal, Prashanth Kandaswamy Employee of: Grunenthal, Heiko Hagedorn Employee of: Grunenthal, Thomas Bardin Consultant for: Astrazeneca, Grunenthal, Horizon, Novartis, Speakers bureau: Astella, AstraZeneca, Grunenthal. DOI: 10.1136/annrheumdis-2019-eular.4679

\section{OP0050 ADDITIVE VALUE AND DIAGNOSTIC ACCURACY OF DUAL-ENERGY CT FOR THE DIAGNOSIS OF GOUT: A PROSPECTIVE STUDY IN SUBJECTS WITH UNCLASSIFIED MONO OR OLIGOARTHRITIS}

Mihaela Gamala ${ }^{1,2}$, Johannes W. G. Jacobs ${ }^{3}$, Suzanne Linn-Rasker ${ }^{4}$, Maarten Nix ${ }^{5}$, Ben Heggelman ${ }^{5}$, Pieternel Pasker ${ }^{6}$, Jacob M. van Laar ${ }^{3}$, Ruth Klaasen ${ }^{4}{ }^{1}$ University Medical Center Utrecht, Rheumatology and Clinical Immunology, Utrechts, Netherlands; ${ }^{2}$ Northwest Clinics, Rheumatology, Alkmaar, Netherlands; ${ }^{3}$ University Medical Center Utrecht, Rheumatology and Clinical Immunology, Utrecht, Netherlands; ${ }^{4}$ Meander Medical Center, Rheumatology, Amersfoort, Netherlands; ${ }^{5}$ Meander Medical Center, Radiology, Amersfoort, Netherlands; ${ }^{6}$ Meander Medical Center, Meander Academy, Amersfoort, Netherlands

Background: The latest diagnostic technique to visualize monosodium uric acid (MSU) depositions is Dual Energy CT scan (DECT). ${ }^{1}$

Objectives: To assess the additive value and accuracy of DECT in diagnosing gout in a prospective study in subjects with unclassified arthritis.

Methods: We included 100 consecutive patients with acute unclassified mono or oligo arthritis who presented to the outpatient clinic of the Department of Rheumatology of Meander Medical Centre, Amersfoort, the Netherlands, ClinicalTrials. gov NCT03038386. Eleven patients dropped out, see Figure. Patients underwent aspiration of the arthritic joint (see Table) and a DECT scan of hands and wrists, knees, ankles and feet bilaterally. The 2015 EULAR/ACR gout classification criteria were used to score the subjects, with and without DECT result, to determine the additive value of DECT. Sensitivity and specificity of DECT for diagnosing gout were calculated separately for at the joint and at individual persons' level, using as reference standards microscopy of synovial fluid (SF) and the gout classification criteria.

Results: For demographic and clinical characteristics of the patients see Table 1, and for study data and outcomes see Figure and Table 2. Sixty-eight of 89 patients $(76.4 \%)$ fulfilled the 2015 EULAR/ACR criteria for gout. Of the 98 patients with SF aspiration, 55 (56\%) were positive for MSU; of these, 89 subjects underwent DECT, of whom 38 had a negative microscopy result. Of these 38 subjects, $14(37 \%)$ met the gout classification criteria only after a positive DECT result.

Conclusion: Our findings suggested that DECT could have an additive value to clinical algorithms in subjects with undifferentiated arthritis when microscopy of $\mathrm{SF}$ fails to demonstrate the presence of MSU crystals.

\section{REFERENCES}

[1] Choi HK, et al. Dual energy CT in gout: a prospectieve validation study. Ann Rheum Dis 2012; 71:1466-71.

Table 1. The characteristics of the patients $(n=89)$ in the analysis

\begin{tabular}{lcc}
\hline & $\begin{array}{c}\text { Patients MSU } \\
\text { positive }(\mathbf{n}=51)\end{array}$ & $\begin{array}{c}\text { Patients MSU } \\
\text { negative }(\mathbf{n}=\mathbf{3 8})\end{array}$ \\
\hline $\begin{array}{l}\text { Age, years, mean (SD) } \\
\text { Gender, N (\%) }\end{array}$ & $60(16)$ & $64(12)$ \\
Male & $44(86.3)$ & $38(73.7)$ \\
Arthritic joint aspirated (N,\%) & & \\
MTP1 & $32(66.7)$ & $8(21.1)$. \\
Other joints & $19(33.3)$ & $31(78.9)$ \\
$\begin{array}{l}\text { Period between } 1^{\text {th }} \text { arthritis attack and } \\
\text { baseline visit in months, median (IQR) } \\
\text { Serum uric acid }(\mu \mathrm{mol} / \mathrm{L}) \text { mean }(\mathrm{SD})\end{array}$ & $12(0.9-48)$ & $5.5(0.2-36)$ \\
\hline
\end{tabular}

Serum uric acid ( $u \mathrm{~mol} / \mathrm{L}$ ) mean (SD)

${ }^{*}$ according to patient

Table 2. Diagnostic accuracy of DECT

\begin{tabular}{|c|c|c|c|c|c|c|c|c|}
\hline $\begin{array}{l}\text { DECT } \\
\text { evaluation } \\
\text { method }\end{array}$ & $\begin{array}{l}\text { Reference } \\
\text { standard }\end{array}$ & TP & FP & FN & $\mathrm{TN}$ & $\begin{array}{l}\text { Sensitivity } \\
(95 \% \mathrm{Cl})\end{array}$ & $\begin{array}{c}\text { Specificity } \\
(95 \% \mathrm{Cl})\end{array}$ & $\begin{array}{c}\text { Diagnostic } \\
\text { accuracy } \\
(95 \% \mathrm{Cl})\end{array}$ \\
\hline $\begin{array}{l}\text { joint/ } \\
\text { localisation } \\
\text { based }\end{array}$ & MSU & 28 & 13 & 23 & 25 & $\begin{array}{c}0.55 \\
(0.40-0.69)\end{array}$ & $\begin{array}{c}0.66 \\
(0.49- \\
0.80)\end{array}$ & $\begin{array}{c}0.60(0.49- \\
0.70)\end{array}$ \\
\hline $\begin{array}{l}\text { patient } \\
\text { based }\end{array}$ & MSU & 39 & 20 & 12 & 18 & $\begin{array}{c}0.77 \\
(0.63-0.87)\end{array}$ & $\begin{array}{c}0.47 \\
(0.31-0.64)\end{array}$ & $\begin{array}{c}0.64(0.53- \\
0.74)\end{array}$ \\
\hline $\begin{array}{l}\text { joint/ } \\
\text { localisation } \\
\text { based }\end{array}$ & $\begin{array}{c}\text { EULAR/ } \\
\text { ACR } 2015\end{array}$ & 41 & 0 & 27 & 21 & $\begin{array}{c}0.60 \\
(0.48-0.72)\end{array}$ & $1(0.84-1)$ & $\begin{array}{c}0.70(0.59- \\
0.79)\end{array}$ \\
\hline $\begin{array}{l}\text { patient } \\
\text { based }\end{array}$ & $\begin{array}{c}\text { EULAR/ } \\
\text { ACR } 2015\end{array}$ & 56 & 3 & 12 & 18 & $\begin{array}{c}0.82 \\
(0.71-0.91)\end{array}$ & $\begin{array}{c}0.86(0.64- \\
0.97)\end{array}$ & $\begin{array}{c}0.83(0.74- \\
0.90)\end{array}$ \\
\hline $\begin{array}{l}\text { joint/ } \\
\text { localisation } \\
\text { based }\end{array}$ & MSU & 11 & 7 & 9 & 12 & $\begin{array}{c}0.55 \\
(0.32-0.76)\end{array}$ & $\begin{array}{c}0.63(0.38- \\
0.84)\end{array}$ & $\begin{array}{c}0.59(0.42- \\
0.74)\end{array}$ \\
\hline $\begin{array}{l}\text { patient } \\
\text { based }\end{array}$ & MSU & 16 & 10 & 4 & 9 & $\begin{array}{c}0.80 \\
(0.56-0.94)\end{array}$ & $\begin{array}{c}0.47(0.24- \\
0.70)\end{array}$ & $\begin{array}{c}0.64(0.46- \\
0.78)\end{array}$ \\
\hline $\begin{array}{l}\text { joint/ } \\
\text { localisation } \\
\text { based }\end{array}$ & $\begin{array}{c}\text { EULAR/ } \\
\text { ACR } 2015\end{array}$ & 18 & 0 & 11 & 10 & $\begin{array}{c}0.60 \\
(0.42-0.79)\end{array}$ & $1(0.69-1)$ & $\begin{array}{c}0.72(0.55- \\
0.85)\end{array}$ \\
\hline $\begin{array}{l}\text { patient } \\
\text { based }\end{array}$ & $\begin{array}{c}\text { EULAR/ } \\
\text { ACR } 2015\end{array}$ & 25 & 1 & 4 & 9 & $\begin{array}{c}0.86 \\
(0.68-0.96)\end{array}$ & $\begin{array}{c}0.90(0.56- \\
0.99)\end{array}$ & $\begin{array}{c}0.87(0.73- \\
0.96)\end{array}$ \\
\hline
\end{tabular}

joint-/localisation-based evaluation, person based evaluation: imaging results positive for gout if green pixilation were observed at the index joint, at the index joint and/or in other locations, respectively.

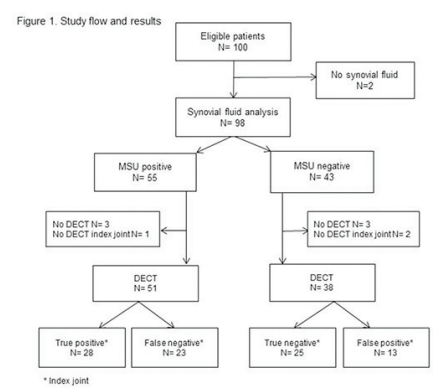

